\title{
Toxoplasma gondii Strains: Bioinformatic Analysis of Heat Shock Protein 60 (Hsp60) Gene in Experimentally Infected Mice
}

\author{
Mona A. Mattar ${ }^{1}$, Rania S. El-Sayed Hamza ${ }^{1}$, Ghada M. Fathy ${ }^{1}$, \\ Tahani I. Farag ${ }^{1}$, Howayda S.F. Moawad ${ }^{1}$, Enas S. El-Bahaie ${ }^{1}$, A.A. \\ Madboli $^{2}$, Ashraf M.A. Barakat ${ }^{3}$ \\ ${ }^{I}$ Department of Medical Parasitology Faculty of Medicine, Zagazig University, Egypt. \\ ${ }^{2}$ Department of Animal Reproduction and Artificial Insemination, Veterinary Research division, \\ National Research Center,Egypt. \\ ${ }^{3}$ Department of Zoonotic Diseases, National Research Center, Egypt.
}

Corresponding Author Tahani Ismail Farag

Mobile:

$+201281244714$

E mail:

tahaniabdelkhalik @yahoo.com

Key words: Toxoplasmosis, $\quad R H$ strain, ME49 strain, Bioinformatics, PCR, Primer 3
Background and study aim: There is a need for more detailed characterisation of $T$. gondii strains to determine the level of genetic variability which is useful in effective diagnosis, treatment and control of toxoplasmosis. This work aimed to assess the difference between the two sequences of Hsp60 gene of both RH and ME 49 strains of $T$. gondii and to investigate its role in the virulence of the parasite.

Materials and Methods: Two strains of T. gondii parasite RH and ME-49 were used for experimental infection of mice groups which were divided into group I (infected with RH strain), group II (infected with ME-49), and group III (non-infected non treated group).

Results: Histopathological examination showed that there was a statistically significant increase in the intensity of infection in liver and spleen of group I and in kidney and brain of group II, with no difference between both groups organs. Molecular and Bioinformatics studies included Primers design using primer 3 program, primer 2 (P2) was selected and used in PCR amplification according to its highest product size $247 \mathrm{bp}$. The results of Insilico PCR amplification program that was carried out to amplify Hsp60 gene theoretically using primer 2 (P2) showed higher number of positive samples that detected in group II than group I, there was significant statistical increase in frequency of brain infection in group II.

Conclusion: Our results showed that PCR was a highly sensitive, specific and rapid technique for detecting $T$. gondii. It revealed higher positive results in chronic strain (ME49) especially in brain tissue than acute strain (RH) but it may show false negative results in some samples. Both PCR technique and histopathological examination showed that the preferred tissue for detection of $T$. gondii in experimentally infected mice was liver \& spleen in acute strain (RH) and brain \& kidney in chronic strain (ME49). Bioinformatic analysis of Hsp60 gene sequences of both (RH \& ME 49) strains of $T$. gondii showed that there was a polymorphism in some nucleotides between the 2 sequences.

\section{INTRODUCTION}

Toxoplasma gondii (T. gondii) is an intracellular protozoan that can infect cells of all warm-blooded animals including birds, livestock, marine mammals and humans [1]. Although toxoplasmosis is generally asymptomatic, primary infection during pregnancy in women and animals may cause abortion, congenital anomalies, or perinatal death [2]. Infection in humans generally occurs either by accidental ingestion of food or water contaminated with sporulated oocysts from faeces of infected cats which is considered as important reservoir or undercooked meats bearing bradyzoite tissue cysts [3]. In addition, $T$. gondii can be also transmitted vertically from an infected mother to her baby during her first gestation [4]. In experimental infection, the severity of toxoplasmosis depends on host and parasite factors as well as the dose and route of inoculation. Oral infection with tissue cysts in mice has been widely used for 
pathological studies, and the small intestine, liver, lungs, spleen and brain are often found to be affected [5]. There are various techniques for diagnosis of toxoplasmosis, but the molecular methods are more sensitive and specific to determine the presence of parasites in clinical sample specially in prenatal diagnosis of congenital toxoplasmosis and in immunocompromised patients, as they do not depend on the immunological status of the host and they are less time consuming [6]. Molecular diagnosis of toxoplasmosis is usually based on the detection of a specific DNA sequence principally from highly conserved regions. It was described that $T$. gondii has a clonal population structure consisting of three genetic lineages i.e., Type I, Type II and Type III [7]. Studies on mice have shown that infections with the different clonal lineages of $T$. gondii result in very different outcomes. Type I strains are highly virulent, whereas type II and type III are relatively nonvirulent. The enhanced virulence of type I strains is in part due to overstimulation of a Th1 immune response that leads to pathology [8]. However, it remains uncertain to what extent the genotype of the parasite directly contributes to the clinical severity of human toxoplasmosis [9]. The variability in the strains has led to speculation that some strains of $T$. gondii might be closely related species with differing pathogenesis in host tissue, therefore, there is a need for more detailed characterization of $T$. gondii strains to determine the level of genetic variation within strains. Knowledge about genetic variability will be useful in the effective diagnosis, treatment and control of toxoplasmosis in humans and animals [10]. Hsp60 plays an important role in intracellular survival, in the differentiation of $T$. gondii and also mediates its virulence [11]. As Hsp60 acts as a mitochondrial chaperone so it is involved in mitochondrial electron transport chain that promote replication of intracellular tachyzoites [12]. Therefore, specific inhibition of the mitochondrial electron transport chain by such drugs as atovaquone and oligomycin, are capable of blocking the replication of tachyzoites, also promote their conversion into encysted bradyzoites so become less virulent [13]. Comparison of genes within a species or between different species can show similarities among protein functions, or relations between species. Sequence alignment is the main process in bioinformatics which is used for measuring the similarity between biological sequences (DNA/ protein), it compares sequences by matching their nucleotides bases to give maximum possible alignment [14].

The aim of the present work is to assess the difference between the two sequences of Hsp60 gene of both RH and ME 49 strains of $T$. gondii and to investigate its role in the virulence of the parasite parasitologically, histopathologically, molecular studies and by using bioinformatic analysis in experimentally infected mice.

\section{MATERIALS AND METHODS}

In this experimental study, two strains RH, ME49 strains were obtained from "Zoonotic Diseases Department, National Research center (NRC)", El Buhouth St., Dokki, Cairo, Egypt. This study was completed in Parasitology Department, Faculty of medicine, Zagazig University, also the molecular study was performed in lab of molecular medical parasitology (LMMP), Medical Parasitology Department, Kasr Al-Ainy Faculty of Medicine, Cairo University. during the period from September 2016 to October 2017.

\section{Ethical consideration:}

Mice were maintained in accordance with the research protocols following the recommendations of the National Institutes of Health Guide for Care and Use of Laboratory Animals, Faculty of Medicine, Zagazig University.

\section{Study design:}

Toxoplasma-free Swiss albino male mice, onemonth-old weighing 25-30 gm were used. All mice were kept in clean cages, fed on Toxoplasma free food and clean water, subsequently infected intraperitoneally with $T$. gondii strains and divided to the following groups: group I: (10 mice) was infected by human RH strain of $T$. gondii, group II: (10 mice) was infected with ME49 strain of T. gondii and group III: negative control group (10 mice).All groups were subjected to The following:

1- Clinical examination: Was performed by Dr. Ashraf Barakat and Dr. Abdelnasser Madboli, group I (RH strain), mice were followed up daily for any apparent clinical signs of acute toxoplasmosis. The predicted signs may be varied between raised and rough hair coat, pendulous abdomen, severe ascites, dullness, tachypnea, nervous manifestations, evidence of early emaciation and dehydration or death 
usually within $72-84$ hours according to Mercier [15].

2- Parasitological examination: Was performed to detect presence or absence of $\mathrm{T}$. gondii tachyzoite, bradyzoites or tissue cysts. Group I (RH strain) peritoneal exudate was collected according to Rougier and Ambroise Thomas [16] and Giemsa staining of peritoneal fluid for tachyzoites according to Brown [17]. Maintenance of infection for RH strain was carried out through serial intraperitoneal passage in mice according to Moreland [18]. For group II (ME 49 strain) collection, homogenization and examination of brain samples after $45^{\text {th }} .60^{\text {th }}$ day post inoculation were performed according to Dubey and Beattie [19]. Tissue cysts were counted microscopically in $50 \mu \mathrm{l}$ of the homogenates, and the count was multiplied by 20 to obtain the number of tissue cysts per one gram.

3- Histopathological study, Suvarna [20]: In group I (RH strain) \& group II (ME 49 strain), tissue samples from liver, spleen, kidney, lung, heart and brain were collected and divided into two compartments; the first compartment fixed in $10 \%$ formalin and kept as a paraffin blocks. Microtome sections were cut at a thickness of $4 \mu \mathrm{m}$. Sections were stained with haematoxlyin and eosin (H\&E), then all slides were examined microscopically. For detection of free tachyzoites, tissue cysts or pseudocyst, while the second one was kept frozen at $\left(-20^{\circ} \mathrm{C}\right)$ in aluminium foil (for all samples except brain samples) for further T. gondii DNA extraction [21]. The 2nd compartment of brain samples were placed in $1 \mathrm{ml}$ of sterile saline and grounded using glass manual homogenizer to release tissue cysts then placed in Eppendorf tubes and kept frozen at $-20{ }^{\circ} \mathrm{C}$ for further $T$. gondii DNA extraction. Regarding group III (control group), mice were sacrificed and tissue samples from liver, spleen, kidney, lung, heart and brain were collected and stored in $10 \%$ formal saline solution for comparative histopathological study only.

\section{4- Molecular and Bioinformatic studies:}

a- Primer design using Primer 3 program according to Rozen and Skaletsky [22] that helped us to decide which portion of the large sequence makes the best primers. The browser was pointed to biotools. umassmed.edu/. This page offering access to several sequence-analysis programs. The Hsp60 gene sequence of $T$. gondii at https://www.ncbi.nlm.nih.gov/gene/79013 62 was copied in FASTA format and pasted in the sequence window.

b- In silico PCR amplification according to San Millán [23]: Calculation of theoretical PCR results by using up-to-date sequenced parasites genomes http://insilico.ehu.es/pcr/ was done . The selected Hsp60 gene was uploaded after saving it in a text/plain file (".txt" extension) with Fasta format then PCR was clicked. After that ATCATCGACCCCACCAAAGT was pasted in the Forward Primer text box and also CAAGCGCTGAGATCCCTTTC pasted in the Reverse Primer text box. Finally, all the default settings were kept and amplify was selected.

c- Polymerase chain reaction (PCR) technique according to Jones [24] was used for detection of T.gondii DNA from frozen tissue samples of both strains. Processing of DNA by PCR involved first DNA extraction from tissues by QuickgDNA $^{\text {TM }}$ Miniprep Kit, Cat. Nos. D3025, Zymo research corporation, followed by T. gondii DNA amplification using one of the primers designed based on Hsp60 gene https://www.ncbi.nlm.nih.gov/gene/790136 2. Primers was ordered from, (Invitrogen, Thermo Fisher Scientific, USA), lastly detection of the amplified products by agarose gel electrophoresis (1.5\%).

Identification and sequencing of the gene was carried out for only 2 samples, liver sample of RH strain (group I) and brain sample of ME49 strain (group II). Sequencing was performed in both directions (forward and reverse direction by direct, automated sequencing (BigDye ${ }^{\circledR}$ Terminator v.3.1 chemistry, Applied Biosystems, USA), using the same primers employed in PCR.

Alignment analysis of the gene sequences was done by two programs; LALIGN and BLAST programs. In LALIGN program available at: https:// embnet.vital-it.ch/software/LALIGN_form.html, the two sequences were pasted in one of the supported formats in the sequence fields. In BLAST program, available at: https://blast. ncbi.nlm.nih.gov/Blast.cgi the two sequences were pasted in one of the supported formats into the sequence fields. 
Statistical analysis:

Collected data were computerized and statistically analyzed using SPSS program (Statistical Package for Social Science) version 25.0. Chi square test was used to calculate difference between qualitative variables in two different groups and fisher exact correction was used when one of the cells had value less than 5 .

\section{RESULTS}

I- Clinical examination results were shown in table (1) and (2):

Table (1): Frequency of different clinical signs among group I:

\begin{tabular}{|l|c|c|c|c|}
\hline \multirow{2}{*}{ Signs } & \multicolumn{2}{|c|}{ +ve } & \multicolumn{2}{c|}{-ve } \\
\cline { 2 - 5 } & $\mathbf{N}$ & $\mathbf{( \% )}$ & $\mathbf{N}$ & $\mathbf{( \% )}$ \\
\hline Raised \& rough hair coat & 2 & $(20)$ & 8 & $(80)$ \\
\hline Tachypnea & 3 & $(30)$ & 7 & $(70)$ \\
\hline Ascites & 6 & $(60)$ & 4 & $(40)$ \\
\hline Fatigue & 5 & $(50)$ & 5 & $(50)$ \\
\hline Loss of appetite \&Emaciation & 5 & $(50)$ & 5 & $(50)$ \\
\hline Death & 0 & $(0)$ & 10 & $(100)$ \\
\hline
\end{tabular}

Table (2): Frequency of different clinical signs among group II

\begin{tabular}{|l|c|c|c|c|}
\hline \multirow{2}{*}{ Signs } & \multicolumn{2}{|c|}{ +ve } & \multicolumn{2}{c|}{-ve } \\
\cline { 2 - 5 } & $\mathbf{N}$ & $\mathbf{( \% )}$ & $\mathbf{N}$ & $\mathbf{( \% )}$ \\
\hline Asymptomatic: & 6 & $(60)$ & 4 & $(40)$ \\
\hline $\begin{array}{l}\text { Nervous manifestations: climbing on wall and } \\
\text { rearing (raise itself upright on its hind legs). }\end{array}$ & 4 & $(40)$ & 6 & $(60)$ \\
\hline Partial off food: & 2 & $(20)$ & 8 & $(80)$ \\
\hline
\end{tabular}

II- Parasitological results: Shown in Table (3) and Fig. (1, 2).

Table (3): Parasitological Examination of Group I \&Group II.

\begin{tabular}{|c|c|c|c|c|c|c|c|}
\hline \multirow[b]{2}{*}{ Sample } & \multicolumn{3}{|c|}{$\begin{array}{c}\text { GroupI } \\
\text { (RH strain) }\end{array}$} & \multicolumn{3}{|c|}{$\begin{array}{c}\text { Group II } \\
\text { (ME } 49 \text { strain) }\end{array}$} & \multirow[b]{2}{*}{ P- value } \\
\hline & + tve & $\overline{\text {-ve }}$ & $\begin{array}{r}\% \\
+\mathrm{ve}\end{array}$ & + tve & $\overline{\text {-ve }}$ & $\begin{array}{r}\% \\
+\mathrm{ve}\end{array}$ & \\
\hline Parasitological examination & 9 & 1 & 90 & 8 & 2 & 80 & $0.53 \mathrm{NS}$ \\
\hline
\end{tabular}

Fisher exact test NS: Non-significant $(p>0.05)$ 


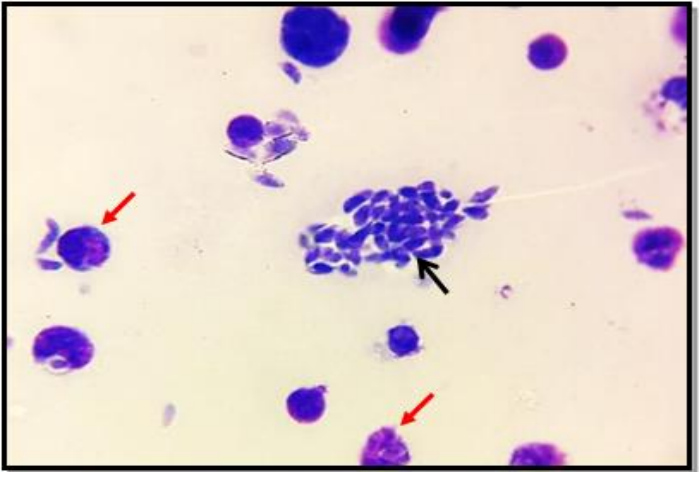

Fig. (1): Peritoneal fluid stained smear of group I (RH strain) exhibited banana shaped $T$. gondii tachyzoite clusters (black arrow) and intact macrophages filled with dividing tachyzoites (pseudocysts) (red arrow). Giemsa stain X 1000

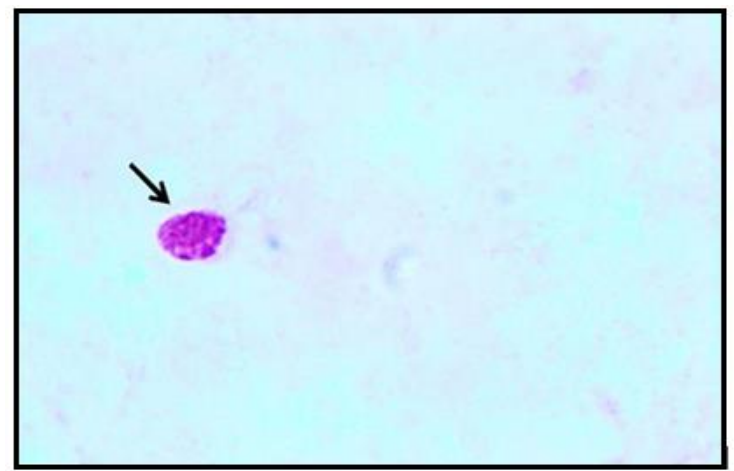

Fig. (2): Stained smear from the brain tissue homogenate of group II (ME 49 strain) showed stained T. gondii cyst which is rounded in shape containing many bradyzoites (arrow). Giemsa stain X 1000 .

III- Histopathological results: Were presented in Fig. (3,4,5,6,7,8,9 and 10).

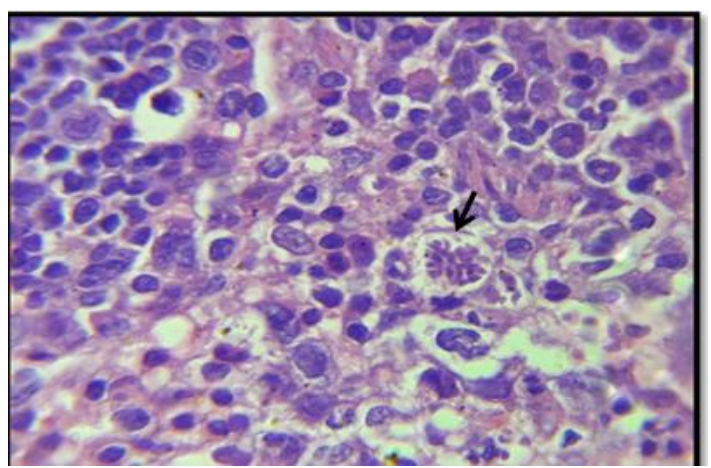

Fig. (3): Spleen section of group I (RH strain) revealed the presence of multifocal clusters of tachyzoites as a pseudocyst of $T$. gondii (black arrow) in the white bulb of spleen. H\&E X 400.

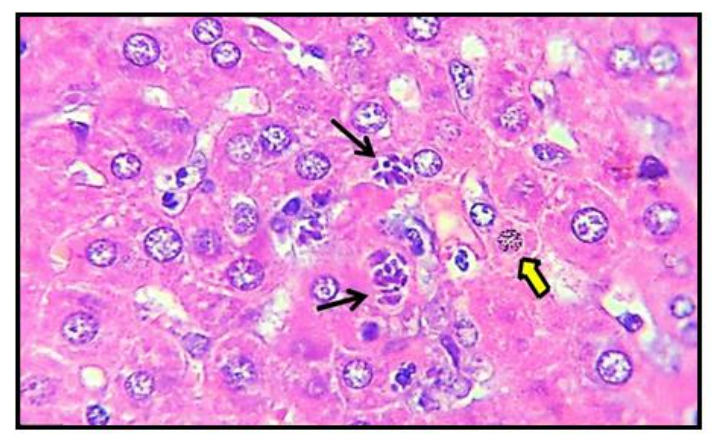

Fig. (5): Liver section of group I (RH strain) showed multiple pseudocyst of $T$. gondii among the hepatic cords (black arrows). Karyorrhexis in nuclei of some hepatocytes were observed (yellow arrow) with degeneration of hepatocytes H\&E X 400 .

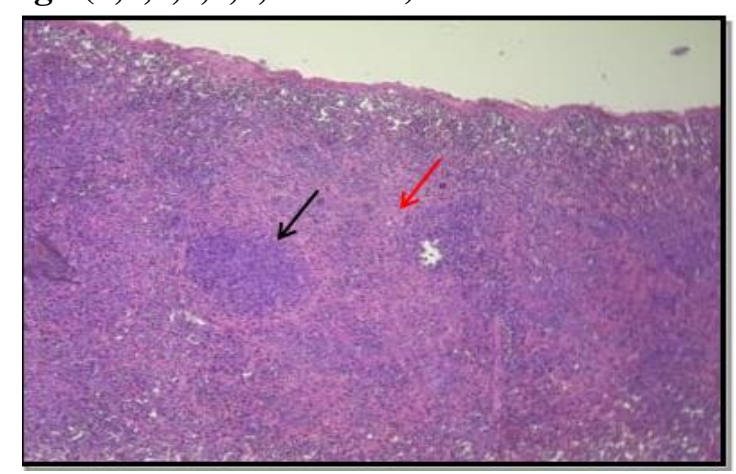

Fig. (4): Spleen section of group III (control group) showed normal architecture of white pulp formed of lymphoid follicle containing many inflammatory cells mainly lymphocytes (black arrow) and red pulp formed of blood sinusoids (red arrow) H\&E X 200.

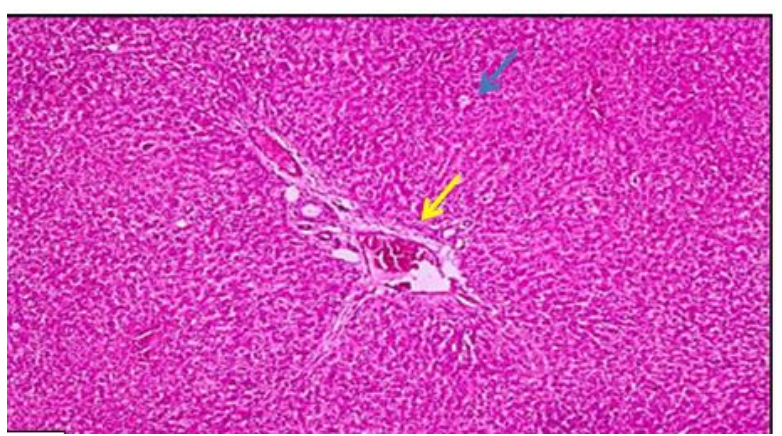

Fig. (6): Liver section of group III (control group) showed normal hepato-portal area (yellow arrow) and thin walled central vein (blue arrow) with normal sized hepatocytes. H\&E X 200. 


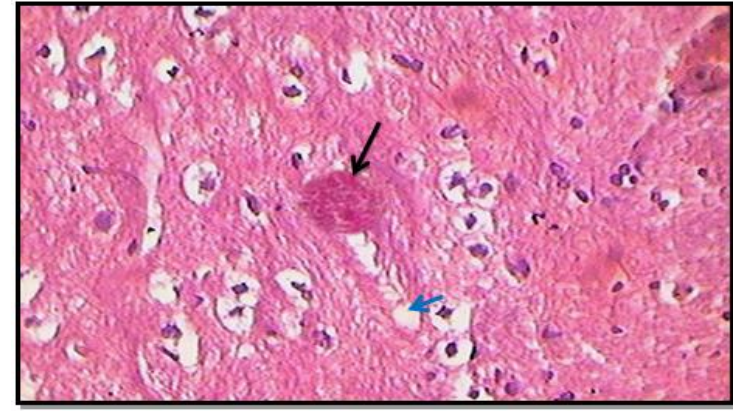

Fig. (7): Brain section of group II (ME 49 strain) showed T.gondii cyst containing many bradyzoites (black arrow) with mild neuronal loss and vacuolar degeneration (blue arrow). H\&E X 400.

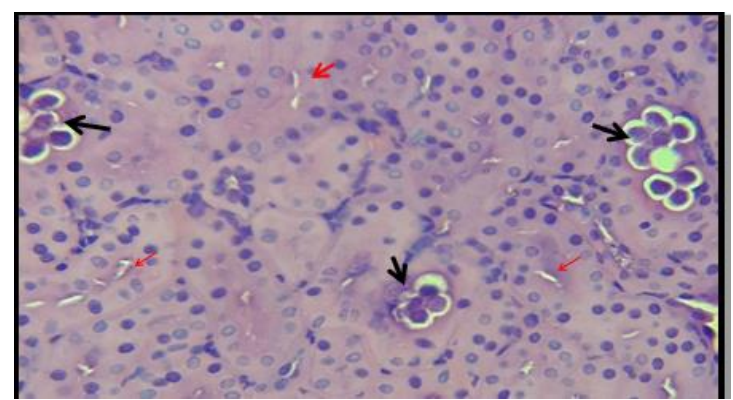

Fig. (9): Kidney section of group II (ME 49 strain) exhibited multiple cysts of $T$. gondii containing bradyzoites, nearly occluded the lumen of the degenerated proximal convoluted tubules (black arrows) and obliterated tubules with no lumen (Red arrows). H\&E X 400.

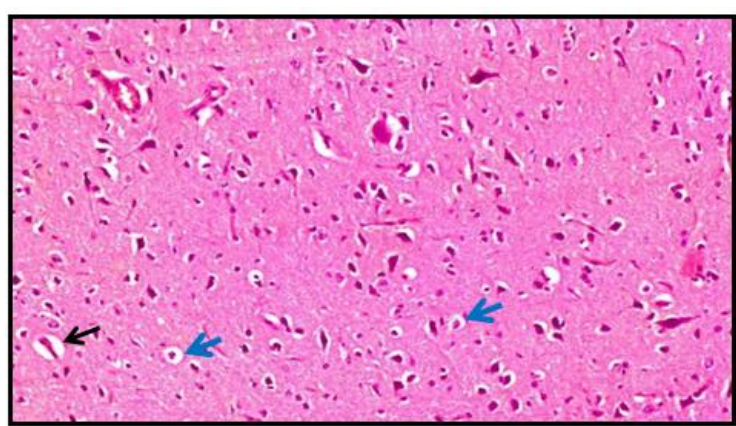

Fig. (8): Brain section of group III (control group) showed completely normal brain tissue as normal glial cells (blue arrows) and capillaries (black arrow) without clear histopathological changes. H\&E X 200

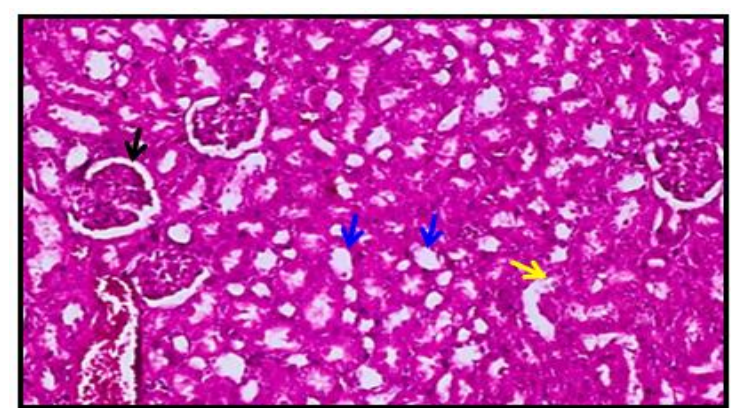

Fig. (10): Kidney section of group III (control group) showed the normal histological structure of the renal glomeruli (black arrow). The proximal convoluted tubules (blue arrow) and distal convoluted tubules (yellow arrow) appear completely normal. H\&E X 200.

Table (4): Comparison between Histopathological Examination (HPE) findings in studied groups

\begin{tabular}{|c|c|c|c|c|c|c|c|}
\hline \multirow[b]{2}{*}{ Tissue Sample } & \multicolumn{3}{|c|}{$\begin{array}{c}\text { Group I (10 mice) } \\
\text { (RH strain) }\end{array}$} & \multicolumn{3}{|c|}{$\begin{array}{l}\text { Group II (10 mice) } \\
\text { (ME } 49 \text { strain) }\end{array}$} & \multirow{2}{*}{$\begin{array}{c}P \\
\text { value }\end{array}$} \\
\hline & $+\mathrm{ve}$ & -ve & $\begin{array}{c}\% \\
+\mathrm{ve}\end{array}$ & $+v e$ & -ve & $\begin{array}{c}\% \\
+\mathrm{ve}\end{array}$ & \\
\hline Liver & 5 & 5 & 50 & 1 & 9 & 10 & $0.04 *$ \\
\hline Spleen & 5 & 5 & 50 & 1 & 9 & 10 & $0.04 *$ \\
\hline Kidney & 2 & 8 & 20 & 6 & 4 & 60 & $0.04^{*}$ \\
\hline Lung & 2 & 8 & 20 & 1 & 9 & 10 & $0.99 \mathrm{NS}$ \\
\hline Heart & 1 & 9 & 10 & 3 & 7 & 30 & $0.58 \mathrm{NS}$ \\
\hline Brain & 1 & 9 & 10 & 5 & 5 & 50 & $0.04 *$ \\
\hline
\end{tabular}

Fisher exact test $\quad$ NS: Non- significant $(\mathrm{p}>0.05) \quad$ *: Significant $(\mathrm{P}<0.05)$

There was a statistically significant increase in the intensity of infection in liver and spleen of group I and in kidney and brain of group II, with no significant difference between both groups in lung and heart. 


\section{IV: Molecular and Bioinformatic Results:}

1- Primer design results: table (5) showed a map of the best oligonucleotide pair forward (F) and reverse (R) primers also called left and right primers respectively. The position, length, predicted melting temperature and GC percentage were given for each primer. In addition, four additional primer pairs were proposed. After the primers were designed, primer 2 (P2) was selected and used in PCR amplification according to its highest product size 247 base pair (bp).

Table (5): The primer designed with primer 3 program and its additional four primer pairs with the specific characters for each

\begin{tabular}{|c|c|c|c|c|c|c|}
\hline & Sequence & Direction & $\begin{array}{c}\text { Product } \\
\text { size }\end{array}$ & $\begin{array}{l}\text { Corresponding } \\
\text { cDNA } \\
\text { nucleotides (bp) }\end{array}$ & GC \% & ${ }^{\circ} \mathbf{T M}{ }^{\circ} \mathbf{C}$ \\
\hline \multirow[t]{2}{*}{$\mathrm{P} 1$} & TGCACATCTACAAGGGCTGA & $\mathrm{F}$ & \multirow{2}{*}{227} & \multirow{2}{*}{$239-466$} & 50 & 59.02 \\
\hline & CAACAACCACAAAACGCCAC & $\mathrm{R}$ & & & 50 & 59.00 \\
\hline \multirow[t]{2}{*}{$\mathrm{P} 2$} & ATCATCGACCCCACCAAAGT & $\bar{F}$ & \multirow{2}{*}{247} & \multirow{2}{*}{ 2872-3119 } & 50 & 59.01 \\
\hline & CAAGCGCTGAGATCCCTTTC & $\overline{\mathrm{R}}$ & & & 55 & 58.99 \\
\hline \multirow[t]{2}{*}{$\overline{\mathrm{P} 3}$} & CGTAGGAGCTCGCTTAGTCA & $\bar{F}$ & \multirow{2}{*}{200} & \multirow{2}{*}{$700-900$} & 55 & 58.98 \\
\hline & $\begin{array}{l}\text { GATCTTGGACAATTCGCGCT } \\
\end{array}$ & $\bar{R}$ & & & 50 & 58.99 \\
\hline \multirow[t]{2}{*}{$\mathrm{P} 4$} & TTGTGAGAGTCTTCGCTGGT & $\bar{F}$ & \multirow{2}{*}{225} & \multirow{2}{*}{$495-720$} & 50 & 58.96 \\
\hline & TGACTAAGCGAGCTCCTACG & $\mathrm{R}$ & & & 55 & 58.98 \\
\hline \multirow[t]{2}{*}{$\overline{\mathrm{P} 5}$} & GAGTTCGTCGCTGTGAATCC & $\mathrm{F}$ & \multirow{2}{*}{204} & \multirow{2}{*}{$205-409$} & 55 & 59.01 \\
\hline & GCAACTGACGGCAACAACTA & $\overline{\mathrm{R}}$ & & & 50 & 59.06 \\
\hline
\end{tabular}

2- In silico PCR Amplification results: In silico PCR amplification program that used to amplify Hsp60 gene theoretically by primer 2 (P2). The length of amplicon was $247 \mathrm{bp}$ and the starting position for amplification was 2872 .

3- PCR technique (extraction and amplification of Hsp60 gene): Figures $(\mathbf{1 1}, \mathbf{1 2})$ showed gel electrophoresis of PCR reaction that targeted Hsp60 of both infected groups (I \&II). The best results were observed in one mouse as a sample compared to other infected mice of the same group. The positive bands appeared in the gel between 200bp and 300bp as the amplified fragment was $247 \mathrm{bp}$ in length according to the best primer selected. Regarding group I Fig. (11) showed also the positive tissue samples :liver, spleen, kidney, lung and brain, while the heart tissue samples were negative in all infected mice of group I. Regarding group II, Fig. (12), the positive tissue samples were liver, spleen, kidney, heart and brain, while the lung tissue samples were negative in all infected mice of group II. 


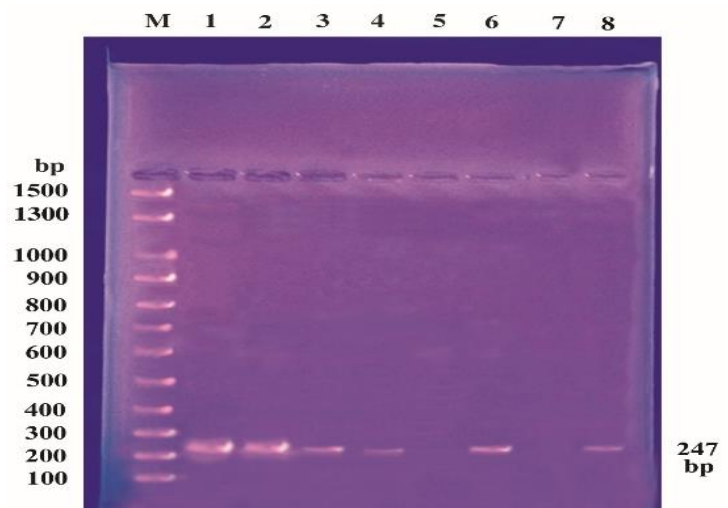

Fig. (11): Agarose gel electrophoresis for products of PCR targeting Hsp60 gene of T. gondii (RH strain) in tissue samples of one mouse at $247 \mathrm{bp}$. Lane 1: liver positive sample, Lane 2: spleen positive sample. Lane 3: kidney positive sample, Lane 4: lung positive sample. Lane 5: heart negative sample, Lane 6: brain positive sample. Lane 7: negative control, Lane 8: positive control. M (marker): DNA molecular size marker

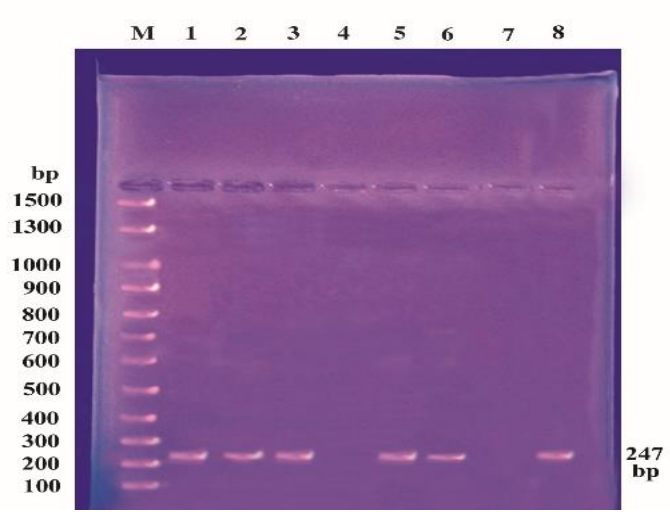

Fig. (12): Agarose gel electrophoresis for products of PCR targeting Hsp60 gene of $T$. gondii (ME49 strain) in tissue samples of one mouse at $247 \mathrm{bp}$. Lane 1: liver positive samples, Lane 2: spleen positive samples. Lane 3: kidney positive samples, Lane 4: lung negative samples. Lane 5: heart positive samples, Lane 6: brain positive samples. Lane 7: negative control, Lane 8: positive control. M (marker): DNA molecular size marker

Table (6): Comparison between PCR findings in studied groups:

\begin{tabular}{|l|c|c|c|c|c|c|c|}
\hline \multirow{2}{*}{ Tissue Sample } & \multicolumn{3}{c|}{$\begin{array}{c}\text { GroupI (10 mice) } \\
\text { PCR strain) }\end{array}$} & \multicolumn{2}{c|}{$\begin{array}{c}\text { Group II (10 mice) } \\
\text { (ME 49 strain) }\end{array}$} & \multirow{2}{*}{ P-value } \\
\cline { 2 - 7 } & +ve & -ve & $\begin{array}{c}\text { \% } \\
\text { +ve }\end{array}$ & +ve & -ve & $\begin{array}{c}\text { \% } \\
\text { +ve }\end{array}$ & \\
\hline Liver & 6 & 4 & 60 & 7 & 3 & 70 & $0.64(\mathrm{NS})$ \\
\hline Spleen & 5 & 5 & 50 & 5 & 5 & 50 & $1(\mathrm{NS})$ \\
\hline Kidney & 2 & 8 & 20 & 6 & 4 & 60 & $0.17(\mathrm{NS})$ \\
\hline Lung & 3 & 7 & 30 & 0 & 10 & 0 & $0.21(\mathrm{NS})$ \\
\hline Heart & 0 & 10 & 0 & 3 & 7 & 30 & $0.21(\mathrm{NS})$ \\
\hline Brain & 1 & 9 & 10 & 6 & 4 & 60 & $\mathbf{0 . 0 3 *}$ \\
\hline
\end{tabular}

Fisher exact test NS: Nonsignificant $(\mathrm{p}>0.05) \quad$ *: Significant $(\mathrm{P}<0.05)$

Table (6) shows PCR findings in GI and GII, higher positive results were found in most organ samples of group II than group I as the percentage of liver, spleen, kidney, lung, heart and brain positive samples in group I were $60 \%, 50 \%, 20 \%, 30 \%, 0 \%$ and $10 \%$ respectively, while in group II the percentage were $70 \%, 50 \%, 60 \%, 0 \%, 30 \%$ and $60 \%$ respectively with significant increase in brain infection $(60 \%)$ in group II.

Table (7): Validity of PCR in diagnosis of infection in liver compared to parasitological study as Gold standard in Group I.

\begin{tabular}{|l|l|c|c|}
\hline \multirow{2}{*}{ PCR } & \multicolumn{2}{c|}{ Parasitological Study } & \multirow{2}{*}{ Total } \\
\cline { 2 - 4 } & \multicolumn{1}{|c|}{+ -ve } & 0 & 6 \\
\hline +ve & 6 & 1 & 4 \\
\hline -ve & 3 & 1 & 10 \\
\hline Total & \multicolumn{2}{|c|}{9} & Specificity: $100 \%$ \\
\hline Validity & NPV: $25 \%$ & \\
\hline Accuracy & Sensitivity:66.7\% $100 \%$ & \multicolumn{3}{|c|}{$70 \%$} \\
\hline
\end{tabular}

Mattar et al., Afro-Egypt J Infect Endem Dis 2019; 9(2): 103-118

https://aeji.journals.ekb.eg/

http://mis.zu.edu.eg/ajied/home.aspx 
Table (7) showed that all parasitological study positive samples were also positive by PCR except 3 samples were PCR negative. There was only one negative sample by both parasitology and PCR. The sensitivity of PCR was (66.7\%), specificity was (100\%), Positive predictive value (P.P.V) was (100\%), Negative predictive value (N.P.V) was (25\%) and the accuracy of PCR in relation to parasitological study was $70 \%$.

Table (8): Validity of PCR in diagnosis of infection in liver compared to parasitological study as gold standard in Group II

\begin{tabular}{|l|c|c|c|}
\hline \multirow{2}{*}{ PCR } & \multicolumn{2}{|c|}{ Parasitological Study } & \multirow{2}{*}{ Total } \\
\cline { 2 - 3 } & +ve & -ve & 7 \\
\hline +ve & 7 & 0 & 3 \\
\hline -ve & 1 & 2 & 10 \\
\hline Total & 8 & 2 & \\
\hline Validity & Sensitivity: $87.5 \%$ & Specificity: $100 \%$ \\
PPV: $100 \%$ & NPV: $66.7 \%$ & \\
\hline Accuracy & \multicolumn{3}{|c|}{$90 \%$} \\
\hline
\end{tabular}

NB: Sensitivity $=$ true positives / (true positive + false negative). Specificity=true negatives/ (true negative + false positives). $\mathbf{P P V}=$ true positive/ (true positive + false positive). $\mathbf{N P V}=$ true negatives/ (true negatives + false negatives). Accuracy $=($ true positive + true negative $) /$ total no.

Table (8) showed that all parasitological study positive samples were also positive by PCR except 1 were negative by PCR. There were 2 negative samples by both parasitology and PCR. The sensitivity of PCR was (87.5\%), specificity was (100\%), Positive predictive value (P.P.V) was (100\%), Negative predictive value (N.P.V) was $(66.7 \%)$ and the accuracy of PCR in relation to parasitological study was $90 \%$.

4- Sequencing and Alignment analysis of Hsp60 gene. Sequencing was carried out for only one positive sample of each mouse in group I (RH strain) and one positive sample of each mouse in group II (ME49 strain). Sequencing was performed in both directions (forward and reverse direction by direct, automated sequencing using the same primers employed in PCR. Then Alignment analysis of Hsp60 gene sequences By LALIGN program as shown Fig (13) showed a total of 5 nucleotide position differences between both RH and ME49 strains of T. gondii. There were 2 nucleotide substitutions detected between the 2 strains at position 95-96 bp, it was (GG) in RH strain sequence and (AT) in ME49 strain. In addition, 3 nucleotide substitutions detected between the 2 strains at position 192-194 bp, it was (TTT) in RH strain sequence and (ACC) in ME49 strain. Similar results were obtained using BLAST program. 


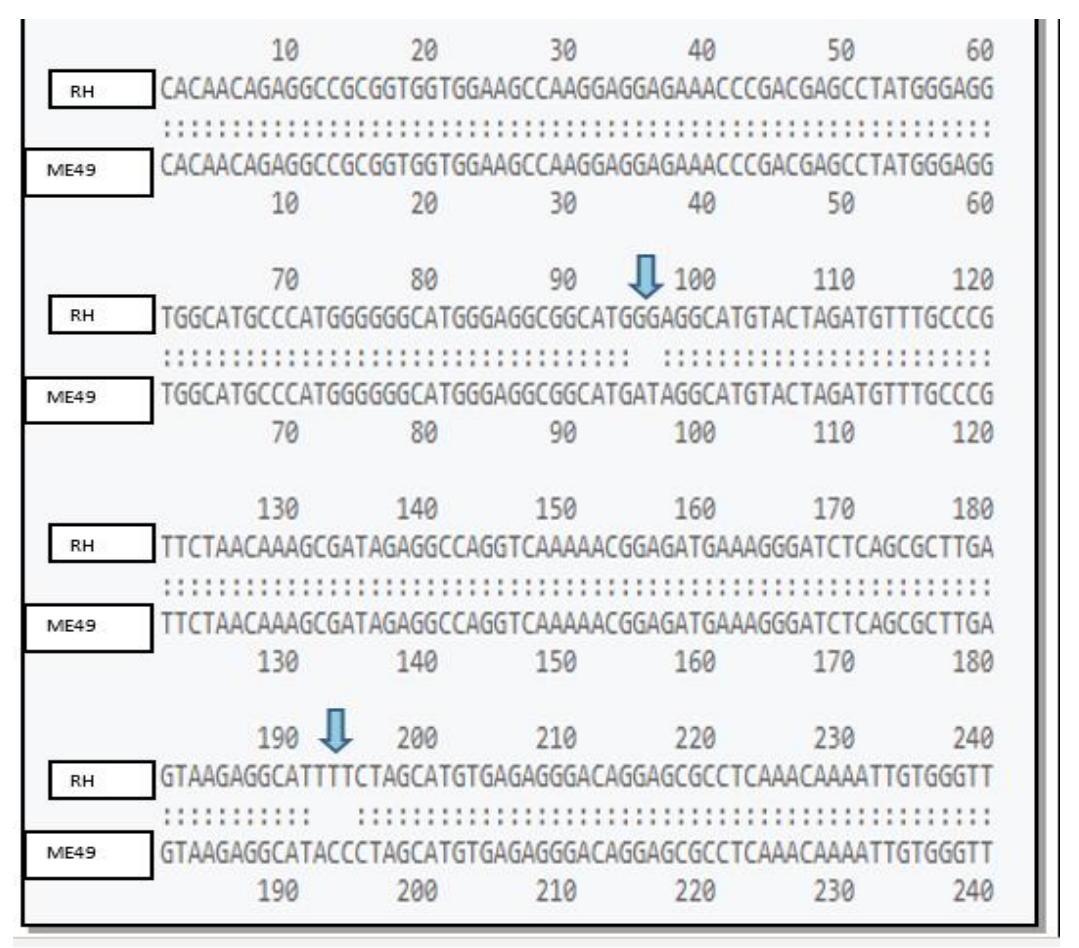

Fig. (13): Analysis of LALIGN program showing polymorphism between RH strain sequence and ME 49 strain sequence in two sites (blue arrow).

\section{DISCUSSION}

Genetic variation among different strains of $T$. gondii has been illustrated through many genetic studies including DNA sequence comparisons [25]. In this study, firstly the bioinformatic studies were used to design the primers specific to T. gondii Hsp60 gene. After that, detection of the parasite using parasitological, histopathological and PCR technique was performed, then sequencing the targeted gene from the PCR amplified fragments of both RH (group I) and ME49 (group II) strains. Alignment analysis of the gene sequences was carried out using alignment programs to determine the difference of HSP60 gene sequence between both strains.

In the current study, clinically we observed some signs on both infected groups, the most observed sign in group I infected with $T$. gondii (RH strain) is ascites (60\%) followed by fatigue (50\%), loss of appetite and emaciation (50\%), tachypnea $(30 \%)$, raised and rough hair coat (20\%). Finally, no death was found among the studied mice These results are in agreement with findings of Waree [26] and Carneiro [27]. The occurrence of these signs can be explained by peritonitis and internal organ inflammation El
Fadaly [28]. In group II infected with $T$. gondii (ME49 strain) most of the mice were asymptomatic $(60 \%)$ and this comes in agreement with Waree [26], followed by nervous manifestation (40\%) that include climbing on wall and rearing (raise itself upright on its hind legs), these signs were in agreement with Carneiro [27] and El Fadaly [28]. The nervous manifestations were explained by encephalitis and brain parasite migration. The difference of clinical manifestation of both groups in this study may be due to the quantity and the parasite strain that was used for the infections El Fadaly [28] and also the habitat of each strain inside the infected mice.

Regarding the parasitological examination in this study; in group I, $90 \%$ of mice were positive for tachyzoites in the peritoneal fluid. While in group II, $80 \%$ of mice were positive for $T$. gondii cysts in brain homogenate with no statistically significant difference between the two groups of infected mice. The only negative sample detected in group I may be due to missed injection in other sites rather than the peritoneal cavity. Also the two negative samples by parasitological examination in group II may be explained that mice being sacrificed early at day 45 after oral inoculation before the infection settled in the 
brain, Yai [29], the infection may also fail due to low or non-viability of parasite in tissue ,Basso [30].

Our histopathological results showed high percentage of positive samples containing tachyzoites were detected in liver and spleen tissue samples in group I. The percentage was $(50 \%)$ for both organs, while in group II were $10 \%$ for both organs too, with statistically significant difference between both infected groups (I \& II). These results were explained that as these organs being adjacent to the peritoneal cavity where tachyzoites were inoculated by intraperitoneal route, it is well known that tachyzoites freely multiply in the lymph nodes and lymphoid tissue drained to liver and spleen, Dubey and Beattie [1]. Concerning the pathological changes in the liver of group I, it appeared as multiple pseudocyst of $T$. gondii among the hepatic cords and karyorrhexis in nuclei of some hepatocytes. Also, the pathological changes in the spleen of the same group appeared as multifocal clusters of tachyzoites as a pseudocyst of $T$. gondii in the white bulb of spleen, these findings are in agreement with Egan [31], Glatman-Zaretsky [32] and Etewa [33]. Pathology that occurred in the liver can be a result of tachyzoite multiplication in hepatocytes and occasionally in kupffer cells, tachyzoites attract inflammatory cells and, when activated, exacerbate the inflammatory response causing cell lysis in addition to the mechanical damage produced by the tachyzoites, Fuentes-Castro [34].

Regarding group II, we detected high percentage of positive samples containing $T$. gondii cysts in kidney $(60 \%)$ \& brain $(50 \%)$ tissue samples, while in group I were $(20 \%)$ in kidney \& $(10 \%)$ in brain tissues with statistically significant difference between both infected groups. The high positivity in brain tissue samples in group II point towards a preferential location of the parasite strain in mouse brains, Dubey [35] and these alterations are caused by parasite molecules that increase the permeability of the bloodbarrier and facilitate the establishment of the parasite. When the parasite infects a large number of astrocytes and glial cells, their protective effect is diminished or lost, which aggravates tissue damage and the inflammatory process, favoring the formation of tissue cysts Strunk [36]. However, absence of brain cysts in group I was explained as brain is an immunologically privileged site, and it is believed that the brain is the last organ to be reached by tachyzoites, in addition the blood-brain barrier slows the influx of mediators of inflammation and antibodies to the brain, which has greater pathological importance in the chronic phase of infection ,Dubey [37]. Similar results were obtained by Smiley [38] and Djurkovic-Djakovic [39]. The pathological changes in brain of group II observed as $T$. gondii cyst containing many bradyzoites with mild neuronal loss and vacuolar degeneration, these findings are in agreement with Gulinello [40], Parlog [41] who observed evidence of inflammatory infiltration and prescence of $T$. gondii cysts. These findings in brain were disagreed by McGavin and Zachary [42], Silva [43] and Nunes [44] who found pathological changes in brain without $T$. gondii cysts.

The high positive samples in renal tissues may be explained by the high vascularity of the kidney and so can be easily contaminated through the blood stream. Similar pathological changes were observed by El Fadaly [28] who observed that there were dilatation of renal blood vessels and degeneration of glomerular tufts and Miranda [45] who detected nephron loss with consequent kidney volume decrease in $T$. gondii infected mice (ME49 strain).

Molecular diagnosis of toxoplasmosis has been mainly performed using Hsp60 gene. The primers were designed to amplify portion of Hsp60 gene. Designing primers based on $T$. gondii ME49 heat shock protein Hsp60 sequence (Gene bank XM_002367081) to detect both RH strain (group I) \& ME49 strain (group II) of $T$. gondii. Previous studies used the same primer to detect most of T.gondii strains ,Anizah [46] and Rahumatullah [47].

Regarding PCR findings in GI and GII (Table 6), higher positive results were found in most organ samples of group II than group I with significant increase in brain infection (60\%) in group II, this was attributed to the number of bradyzoites found inside a cyst has a magnitude order higher than the tachyzoites, favoring the DNA extraction and amplification of the mice organ samples. This finding was in agreement with Terra [48] who observed higher positive tissue samples in chronic infection group than acute infection group. Other study by Rahumatullah [47] disagreed with this finding, they observed that RH-infected mice generally showed higher parasite loads in all tissue organs as compared to ME49 strain-infected mice except with brain

Mattar et al., Afro-Egypt J Infect Endem Dis 2019; 9(2):103-118

https://aeji.journals.ekb.eg/

http://mis.zu.edu.eg/ajied/home.aspx 
sample. Our results showed that heart tissue samples did not show any amplification in group I $(0 \%)$ and it could be attributed to absence of tachyzoites in these tissues owing to acute phase of infection and tachyzoites did not get enough time to reach to this organ. This finding is in agreement with Sudan [49]. On the other hand, Dadimoghaddam [50] found that the high parasite load in all tissues and the peak of DNA was observed in heart, kidney and liver in experimentally infected mice with $T$. gondii $\mathrm{RH}$ strain.

The ultimate significance of PCR based detection of toxoplasmosis is that PCR can detect the DNA of parasites even when the tissues available for testing are in state of decomposition; in contrast in histopathology it is quite difficult to identify the necrosed tachyzoites in the regions of marked generalized necrosis of the tissues induced by tachyzoites themselves ,Hurtado [51] and Yai [29]. Absence of T. gondii parasite in histological sections however it was detected by PCR may be explained by the difficulty in detecting the parasite due to the uneven and clustered distribution of the parasite in tissue, Bezerra [52], or may be explained as only a small amount of tissue can be fixed on one slide and as few as one tissue cyst can be present in an entire organ, so the parasite may be present in unexamined tissues, Bouchard [53]. Selection of liver tissues to determine the PCR sensitivity depending on the highest intensity of infection in both infected groups as liver of mice infected with group I \& II showed the highest parasite load, followed by other organs, this finding was in agreement with Rahumatullah [47] who showed highest parasite load in liver tissue of RH \&ME49 strains.

The sensitivity of PCR was (66.7\%) in group I, out of 9 positive samples by parasitological examination, 3 samples were not detected by PCR technique. This finding resulted from limited sample size, random distribution of tachyzoites in tissue or may be due to low number of parasites in tissues, Hill [54]. Other studies reported high PCR sensitivity, Hafid [55] (2 tachyzoites) and El sayed Khalifa [56] (1 tachyzoite).

The sensitivity of PCR was (87.5\%) in group II, out of 8 positive samples by parasitological examination, only one sample was not detected by PCR technique. These results are in agreement with findings obtained from Hamidinejat [57] who detected $46.23 \%$ of chicken infected with $T$. gondii by PCR compared to $27.36 \%$ by mouse bioassay, Also, Saki [58] reported $6 \%$ positive samples in rodents by PCR but $2 \%$ positive samples by mouse bioassay. On the contrary, the results obtained from Tsutsui [59] identified T.gondii in pork by mouse bioassay and PCR in $67.5 \%$ and $22.5 \%$ respectively.

Alignment analysis of Hsp60 gene sequences revealed a total of 5 nucleotide position differences between both RH and ME49 strains of $T$. gondii. There were 2 nucleotide substitutions detected between the 2 strains at position 95-96 bp, it was (GG) in RH strain sequence and (AT) in ME49 strain. In addition, 3 nucleotide substitutions detected between the 2 strains at position 192-194 bp, it was (TTT) in RH strain sequence and (ACC) in ME49 strain. Similar results were obtained by Lilue [60] which involved the comparison of 315 bp sequence from the 3' regions of the SAG1 gene from nine strains of $T$. gondii detected polymorphisms correlated with virulence.

These differences between the two sequences can provide valuable information in detecting mutational changes between closely related strains which might otherwise be concealed when looking at protein coding sequences or might change in protein function, Binas [61]. Also definition of a $T$.gondii strain as murine virulent or nonvirulent without needing to test it in vivo, Cheng [62]. Lyons and Johnson [63] reported that Hsp70 demonstrated after transcription in virulent strains of $T$. gondii and compared with avirulent strains suggesting that Hsp70 play an important role in the virulence of T. gondii. So, in this study, the sequence of $T$. gondii Hsp60 (RH strain) may be after gene expression, provide protection for this strain against cell damage associated with host cell invasion, allowing the virulent strain to persist as tachyzoites without the requirement for the encystation observed in avirulent strains.

As Hsp60 is thought to be located to the mitochondria of eukaryotes, where it helps in protein homeostasis, these chaperon systems involve multiple types of PPIs (protein interactions) that ensures proper protein folding and degradation, Koldewey [64]. Recent efforts have yielded chemical probes or inhibitors which are small molecules that inhibit (or promote) PPIs and so inhibit or promote molecular chaperone, Gestwicki and Shao [65]. Therefore, gene expression and protein translation of $T$. 
gondii Hsp60 (ME 49 strain) could be smoothly happened but later on it may be inhibited by these chemical inhibitors.

So, the difference between the virulence of the two strains may be due to the difference in their sequence as approved by our results and consequently the difference in the sequence of amino acids and the produced protein, it may be also due to production of the same protein and then its inhibition by these chemical mediators.

Another explanation for avirulence of ME49 strains, as DNA molecule is a double helix, therefore either side can serve as a template to be copied by RNA, the genetic information is stored in a sequence of nitrogenous bases that get transcribed by mRNA. Every three bases is called a codon, the mRNA codon is actually the information that gets translated into protein, Sadowski and Jones [66]. Altered codon leads to insertion of an incorrect amino acid into a protein molecule during translation, so the protein function may be altered or the codon may be unaltered and codes for the same amino acid, Sauna and Kimchi-Sarfaty [67].

\section{CONCLUSION}

Our results showed that PCR is a highly sensitive, specific and rapid technique for detecting $T$. gondii. It revealed higher positive results in chronic strain (ME49) especially in brain tissue than acute strain $(\mathrm{RH})$ but it may show false negative results in some samples. Both PCR technique and histopathological examination showed that the preferred tissue for detection of T. gondii in experimentally infected mice was liver \& spleen in acute strain $(\mathrm{RH})$ and brain \& kidney in chronic strain (ME49). Bioinformatic analysis of Hsp60 gene sequences of both (RH \& ME 49) strains of $T$. gondii showed that there was a polymorphism in some nucleotides between the 2 sequences. This polymorphism might change in protein function or may be concealed after protein translation. The results of the present study suggested that the coding region of the Hsp60 gene may represent a genetic marker for further intraspecies phylogenetic analyses of $T$. gondii. Further studies are needed to investigate whether Hsp 60 gene polymorphism affects $T$. gondii strains virulence or not.

\section{Ethical considrations:}

Mice were maintained in accordance with the research protocols following the recommendations of the National Institutes of Health Guide for
Care and Use of Laboratory Animals, Faculty of Medicine, Zagazig University.

Funding: None.

\section{Conflicts of interest:}

There are no conflicts of interest.

\section{REFERENCES}

1- Dubey, JP and Beattie, CP. Toxoplasmosis of animals and man. 2nd ed. Florida, Boca Raton: CRC Press, 2010; p. 1-313.

2- Yarovinsky, F. Innate immunity to Toxoplasma gondii infection. Nature Reviews Immunology, 2014, 14: 109121.doi:10.1038/nri3598PMID:24457485.

3- Gontijo da Silva, M; Clare Vinaud, $M$ and de Castro, AM. Prevalence of toxoplasmosis in pregnant women and vertical transmission of Toxoplasma gondii in patients from basic units of health from Gurupi, Tocantins, Brazil, from 2012 to 2014. PLoS One 2015.,10 (11), e0141700.

4- Holland, GN. Ocular toxoplasmosis: a global reassessment. PartI: epidemiology and course of disease. Am J Ophthalmol; 2003, 136:973-988.

5- Egan CE; Maurer KJ; Cohen SB; Mach M; Simpson KW and Denkers, EY. Synergy between intraepithelial lymphocytes and lamina propria $\mathrm{T}$ cells drives intestinal inflammation during infection. 2011, Mucosal Immunol. 4 (6), 658-670.

6- Tlamçani, Z; Lemkhenete, Z and Lmimouni BE. Toxoplasmosis: The value of molecular methods in diagnosis compared to conventional methods Journal of Microbiology and Infectious Diseases; 2013, 3 (2): 93-99.

7- Howe, DK and Sibley, LD. Toxoplasma gondii comprises three clonal lineages: correlation of parasite genotype with human disease. J Infect Dis., 1995, 172: 1561-1566.

8- Mordue, DGF; Monroy M; La Regina, CA and Sibley, LD. Acute toxoplasmosis leads to lethal overproduction of Th1 cytokines. J. Immunol. 2001, 167:4574-4584.

9- Khan A; Behnke M; Dunay IR; White MW and Sibley LD. Phenotypic and gene expression changes among clonal type I strains of Toxoplasma gondii. Eukaryot. Cell; 2009, 8, 1828e1836.

10- Saraf P; Shwab EK; Dubey Jr. P and Su C. On the determination of Toxoplasma gondii virulence in mice. Experimental Parasitology; 2017,174: 2530. 
11- Shonhai A; Maier AG; Przyborski JM and Blatch, GL. Intracellular protozoan parasites of humans: the role of molecular chaperones in development and pathogenesis. Protein Pept. Lett; 2011,18: 143-157.

12- Bukau, B and Horwich, AL. The Hsp70 and Hsp60 chaperone machines. Cell: 1998 ,92:35166.

13- Toursel C; Dzierszinski F; Bernigaud A; Mortuaire $\mathrm{M}$ and Tomavo, S. Molecular cloning, organellar targeting and developmental expression of mitochondrial chaperone HSP60 in Toxoplasma gondii. Mol Biochem Parasitol.; 2000, 111:319332.

14- Dixit, P and Prajapati, GI. Machine learning in bioinformatics: A novel approach for DNA sequencing. In Advanced Computing \& Communication Technologies (ACCT), Fifth International Conference 2015 on, pages 41-47. IEEE.

15- Mercier A; Devillard S; Ngoubangoye B; Bonnabau $\mathrm{H}$; Bañuls $\mathrm{A}$; Durand $\mathrm{P}$ et al. Additional Haplogroups of Toxoplasma gondii out of Africa: Population Structure and Mouse-Virulence of Strains from Gabon. PLoS Negl. Trop. Dis.; 2010, 4 (11): e876.

16- Rougier, D and Ambroise-Thomas, P. Detection of toxoplasmic immunity by multipuncture skin test with excretory secretory antigen. Lancet; 1985, 11: 121-123.

17- Brown AB. Hematology: Principles and Procedures, Sixth Edition, Lea \& Febiger, Philadelphia, 1993, p101.

18- Moreland, AF. Collection and withdrawal of body fluids and infusion techniques. In: "Methods of Animal Experimentation", W.I. Gay, ed.: 1965, Vol. 1, PP. 1: 42. Academic Press, New York, San Francisco/London.

19- Dubey JP and Beattie CP. Toxoplasmosis of Animals and Man. CRC Press Boca Raton, Florida. 1988.

20- Suvarna, K; Layton, C and Bancroft, J. Theory and Practice of 417 Histological Techniques, 7th ed: 2012, Churchill Livingstone, London, United Kingdom.

21- Sudan, V; Tewari, AK; Singh, H and Singh, R. Pathobiology of human RH strain induced experimental toxoplasmosis in murine model. $J$ Parasit Dis; 2014. DOI g,10.1007/s12639-0140589-1.

22- Rozen S and Skaletsky HJ. Primer3 on the WWW for general users and for biologist programmers. In: Krawetz S, Misener S (eds) Bioinformatics Methods and Protocols: Methods in Molecular Biology. Humana Press, Totowa, NJ: 2000, pp 365-386.
23- San Millán, RM; Martínez-Ballesteros, I; Rementeria, A; Garaizar, J and Bikandi, J. Online exercise for the design and simulation of PCR and PCR-RFLP experiments. BMC Research Notes: 2013, 6:513. DOI: $\underline{10.1186 / 1756-0500-6-513}$.

24- Jones, CD; Okhravi, N; Adamson, P; Tasker, S and Lightman, S. Comparison of PCR Detection Methods for B1, P30, and 18S rDNA Genes of Toxoplasma gondii in Aqueous Humor. Invest. Ophthalmol. Vis. Sci.; 2000, 41 (3): 643-646.

25- Homan WL; Limper L; Verlaan M; Borst A; Vercammen $\mathrm{M}$ and Knapen F. Comparison of the internal transcribed spacer 1 from Toxoplasma gondii isolates and Neospora caninum. Parasitol Res; 1998 ,83: 285-289.

26- Waree P; Ferguson DJ; Pongponratn E; Chaisri $\mathrm{U}$ and Sukthana, Y. Immunohistochemical study of acute and chronic toxoplasmosis in experimentally infected mice., Southeast Asian J Trop Med Public Health; 2007, 38(2): 223-31.

27-Carneiro ACAV; Carneiro AMG; Gouveia Guimarães AS; Marques APR; Vilas-Boas LS and Vito, RWA. Seroprevalence and risk factors of caprine toxoplasmosis in Minas Gerais, Brazil. Vet. Parasitol.; 2009, 160: 225-229.

28- El Fadaly, HA; Soror, AH; Barakat, AMA and Abd El-Razik, KA. Zoonotic and histo-pathological aspects of various Toxoplasma gondii strains in female rats., Afr. J. Infect. Dis.; 2015, 9(2): 32-38.

29- Yai, LEO; Vianna, MCB and Soares, RM. "Evaluation of experimental Toxoplasma gondii (Nicolle and Manceaux, 1909)infection in pigs by bioassay in mice and polymerase chain reaction," Brazilian Journal of Veterinary Research and Animal Science, 2003 ,vol. 40, no. 3, pp. 227-234.

30- Basso, W; Hartnack, S; Pardini, L; Maksimov, P; Koudela, B and Venturini, MC. Assessment of diagnostic accuracy of a commercial ELISA for the detection of Toxoplasma gondii infection in pigs compared with IFAT, TgSAG1-ELISA and Western blot, using a Bayesian latent class approach. Int J Parasitol.; 2013, 43(7):565-70.

31- Egan, CE; Cohen, SB and Denkers, EY. Insights into inflammatory bowel disease using Toxoplasma gondii as an infectious trigger. Immunol Cell Biol.; 2012 ,90(7): 668-75.

32- Glatman-Zaretsky, AG; Silver, JS; Siwicki, M; Durham, A; Ware, CF and Hunter, CA. Infection with Toxoplasma gondii alters lymphotoxin expression associated with changes in splenic architecture. Infect Immun; 2012, 80 (10): 3602-10. 
33- Etewa SE, El-Maaty DAA, Hamza RS, Metwaly AS, Sarhan MH, Abdel-Rahman SA et al. Assessment of spiramycin-loaded chitosan nanoparticles treatment on acute and chronic toxoplasmosis in mice. J Parasit Dis. 2018 Mar;42(1):102-113. doi: 10.1007/s12639-0170973-8. Epub 2017 Dec 15. PubMed PMID: 29491568; PubMed Central PMCID: PMC5825375.

34- Fuentes-Castro, BE; Reyes-García, JG; ValenzuelaVargas, MT and Martínez-Gómez, F. Histopathology of murine toxoplasmosis under treatment with dialyzable leukocyte extract Mem Inst Oswaldo Cruz, Rio de Janeiro; 2017, Vol. 112(11): 741-747.

35- Dubey, JP. Advances in the life cycle of Toxoplasma gondii. Int J Parasitol; 1998 ,28: 1019-1024.

36- Strunk T; Inder T; Wang X; Burgner, D; Mallard, $\mathrm{C}$ and Levy, O. Infection-induced inflammation and cerebral injury in preterm infants. Lancet Infect Dis; 2014, 14(8): 751-62.

37- Dubey, JP; Ferreira, LR; Martins, J and McLeod, R. Oral oocysts-induced mouse model of toxoplasmosis: effect of infection with Toxoplasma gondii strains of different genotypes, dose, and mouse strains (transgenic, out-bred, in-bred) on pathogenesis and mortality. Parasitology; 2012, 139 (1), 1-13.

38- Smiley ST; Lanthier PA; Couper KN; Szaba FM; Boyson JE and Chen W. Exacerbated susceptibility to infection-stimulated immunopathology in CD1d deficient mice. J. Immunol.; 2005, 174 (12), 7904-7911.

39- Djurkovic-Djakovic O; Klun I; Khan A; Nikolic, A; Knezevic-Usaj S and Bobic B. A human origin type II strain of Toxoplasma gondii causing severe encephalitis in mice. Microbes Infect.; 2006, 8 (8), 2206-2212.

40- Gulinello, M; Acquqrone, M; Kim, JH; Spray, DC; Barbosa, HS; Sellers, R. Acquired infection with Toxoplasma gondii in adult mice results in sensorimotor deficits but normal cognitive behavior despite widespread brain pathology. Microbes Infect.; 2010, 12(7): 528-37.

41- Parlog, A; Schlüte, D and Dunay, IR. Toxoplasma gondii-induced neuronal alterations. Parasite Immunol.; 2015, 37(3): 159-70.

42- McGavin, MD and Zachary, JF. Pathologic basis of veterinary disease. Missouri: Mosby. Can Vet J.; 2007, 48(7): 724.
43- Silva AF. Anátomo-histopatologia, imunohistoquímica e análises clínicas de ovinos infectados naturalmente por Toxoplasma gondii e Neospora caninum no estado do Rio de Janeiro [Master Dissertation]. Rio de Janeiro:2011, Universidade Federal Fluminense.

44- Nunes AC; da Silva EM; de Oliveira JA; Yamasaki EM; Kim PD; de Almeida JC et al. Application of different techniques to detect Toxoplasma gondii in slaughtered sheep for human consumption. Braz. J. Vet. Parasitol., Jaboticabal,2015. Doi: http://dx.doi.org/10.1590/S1984-29612015076.

45- Miranda FJ B; de Souza DB; Frazão-Teixeira E; de Oliveira FC; de Melo JC; Mariano CMA et al. Experimental infection with the Toxoplasma gondii ME-49 strain in the Brazilian BR-1 mini pig is a suitable animal model for human toxoplasmosis, Mem Inst Oswaldo Cruz, Rio de Janeiro; 2015, Vol. 110(1): 95-100.

46- Anizah, R; Khoo, BY and Rahmah, N. Triplex PCR using new primers for the detection of Toxoplasma gondii. Experimental Parasitology; 2012, 131: 231-238.

47- Rahumatullah, A; Khoo, BY and Noordin, R. Development of triplex real-time PCR and detection of Toxoplasma gondii DNA in infected mice tissues and spiked human samples; Tropical Biomedicine; 2015, 32(2): 376-385.

48- Terra, MA; Bello, AR; Bastos, OM; Amendoeira, MR; Coelho, JM; Ferreira, LF and Araújo, A. Detection of Toxoplasma gondii DNA by polymerase chain reaction in experimentally desiccated tissues. Mem Inst Oswaldo Cruz.; 2004, 99(2):185-8.

49- Sudan, V; Tewari, AK; Singh, R and Singh, H. Comparison of histopathology and PCR based assay for detection of experimentally induced toxoplasmosis in murine model, Asian Pacific Journal of Tropical Medicine; 2015, 8(6): 447450.

50- Dadimoghaddam Y; Daryani A; Sharif M; Ahmadpour $\mathrm{E}$ and Hossienikhah Z. Tissue tropism and parasite burden of Toxoplasma gondii RH strain in experimentally infected mice; Asian Pacific Journal of Tropical Medicine; 2014, 521-524.

51- Hurtado, A; Aduriz, G; Moreno, B; Barandika, J; Garcia-Perez, AL. Single tube nested PCR for the detection of Toxoplasma gondii in fetal tissues from naturally aborted ewes. Vet Parasitol; 2001, 102:17-27. 
52- Bezerra RA; Carvalho FS; Guimarães LA; Rocha, DS; Silva FL; Wenceslau AA and Albuquerque, GR. Comparison of methods for detection of Toxoplasma gondii in tissues of naturally exposed pigs; Parasitol Res; 2012, 110:509-514.

53- Bouchard, É; Sharma, R; Bachand, N; Gajadhar, AA; and Jenkins, EJ. Pathology, clinical signs, and tissue distribution of Toxoplasma gondii in experimentally infected reindeer (Rangifer tarandus); Int J Parasitol Parasites Wildl.; 2017, 6(3): 234-240.

54- Hill, DE; Chirukandoth, S and Dubey, JP: Biology and epidemiology of Toxoplasma gondii in man and animals. Anim. Health Res. Rev; 2005, 6 (1), 41-61.

55- Hafid, J; Flori, P and Raberin, H. Comparison of PCR, Capture ELISA and immunoplotting for detection of $T$. gondii in infected mice; J. Med. Microbiology; 2001, 50, pp 1100-111.

56- El Sayed Khalifa K; Roth A; Roth B; Arasteh KN and Janitschke K. value of PCR for evaluating occurrence of parasitemia in immunecompromised patients with cerebral and extracerebral toxoplasmosis, J Clin Microbiol; 1994, 32: 2819-2819.

57- Hamidinejat H; Nabavi L; Mayahi M; Ghourbanpoor M; Pourmehdi Borojeni M; Norollahi Fard S and Shokrollahi, M. Comparison of three diagnostic methods for the detection of Toxoplasma gondii in free range chickens. Tropical Biomedicine; 2014, 31(3): 507-513.

58- Saki, J and Khademvatan, S. Detection of Toxoplasma gondii by PCR and Mouse Bioassay in Rodents of Ahvaz District, Southwestern Iran., Hindawi Publishing Corporation, BioMed Research International;2014. Article ID 383859, 5 pages http://dx.doi.org/10.1155/2014/383859.
59- Tsutsui, VS; Freire, RL; Garcia, JL; Gennari, SM; Vieira, DP; Marana, ERM et al. Detection of Toxoplasma gondii by PCR and mouse bioassay in commercial cuts of pork from experimentally infected Pigs; Arq. Bras. Med. Vet. Zootec.; 2007 ,59(1): 30-34.

60- Lilue J; Müller UB; Steinfeldt T and Howard JC. Reciprocal virulence and resistance polymorphism in the relationship between Toxoplasma gondii and the house mouse. Elife. 2013;2: e01298. Published 2013 Oct 29. doi:10.7554/eLife.01298.

61- Binas, M and Johnson, AM. A polymorphism in a DNA polymerase a gene intron differentiates between murine virulent and avirulent strains of Toxoplasma gondii International Journal for Parasitology; 1998, 28: 1033-1040.

62- Cheng W; Wang C; Xu T; Liu F; Pappoe F; Luo $\mathrm{Q} ; \mathrm{Xu} \mathrm{Y}$; LuF and Shen, J. Genotyping of polymorphic effectors of Toxoplasma gondii isolates from China; Parasites \& Vectors; 2017, 10:580.

63- Lyons, RE and Johnson, AM. Gene sequence and transcription differences in $70 \mathrm{kDa}$ heat shock protein correlate with murine virulence of Toxoplasma gondii. International Journal for Parasitology; 1998, 1041-1051.

64- Koldewey, P; Horowitz, S and Bardwell, JCA. Chaperone -client interactions: Non -specificity engenders multifunctionality. J Biol Chem; 2017, 292, $12010-12017$.

65- Gestwicki JE and Shao H. Inhibitors and chemical probes for molecular chaperone networks J. Biol. Chem., 2018 in Press.

66- Sadowski MI and Jones DT. The sequence-structure relationship and protein function prediction., Current opinion in structural biology:2009, 19 (3) 357-362.

67- Sauna, ZE and Kimchi-Sarfaty, C. Understanding the contribution of synonymous mutations to human disease. Nat Rev Genet.; 2011, 31; 12(10): 68391. 